(Uniwersytet Kardynała Stefana Wyszyńskiego, Warszawa,

e-mail: a.marcisz@uksw.edu.pl)

ORCID: 0000-0002-9215-2030

\title{
CZY WYCZYN TO WYJĄTKOWY CZYN? O SEMANTYCE LEKSEMÓW WYCZYN I CZYN UWAGI WSTEPNE
}

\author{
Jest $z$ pewnościa bardzo \\ trudno określić naturę człowieka. \\ Wykracza on poza wszelkie ramy \\ nadawanych mu określeń przez swoje czyny, \\ czasem bohaterskie, a czasem straszliwe...
}

[Ingarden 1975, 21]

Gdyby wziać pod uwagę definicję leksemu wyczyn z ISJP, która brzmi: 'wyczyn to wyjątkowy czyn, który wymagał od kogoś ogromnego wysiłku, odwagi, sprytu lub wielkich umiejętności. Słowo używane z podziwem', ${ }^{1}$ należałoby uznać wyczyn za czyn różniący się od samego czynu tym, że jest wyjatkowy. Przymiotnik wyjątkowy definiowany jest w ISJP następująco: 1. 'Mówimy, że jakieś osoby, rzeczy, sytuacje itp. są wyjątkowe, aby podkreślić, że maja jaką́s rzadka i zwykle cenną cechę'; 2. 'Wyjątkowe sytuacje i zdarzenia sa niezwykłe i występuja rzadko'. Ze zdania: Jan dokonał wyjatkowego czynu nie wynika jednak, że Jan dokonał wyczynu. Muzeum Powstania Warszawskiego przyznaje Nagrodę im. Jana Rodowicza „Anody” za wyjątkowy czyn, np. podjęcie błyskawicznej decyzji ratowania zagrożonego życia ludzkiego. W poprzednich edycjach jury nagrodziło m.in. nastolatka, który wskoczył do rzeki i uratował dwoje tonących dzieci, policjanta, ratującego mężczyznę $z$ ogarniętego pożarem budynku, czy studenta, który będąc na wakacjach, ocalił życie czterech osób. Uratowanie komuś życia to niewątpliwie wielki i wyjątkowy czyn, ale czy taki czyn jest jednocześnie wyczynem?

1 Podobna definicję omawianego słowa znajdziemy w Wielkim słowniku języka polskiego; brzmi ona następujacco: wyczyn - 'czyn, którego dokonanie zdarza się rzadko i jest bardzo trudne, ponieważ wymaga wielu umiejętności lub wielkiego wysiłku i z tego powodu budzi podziw u innych osób' [WSJP: https:// wsjp.pl/]. 


\section{Według Magdaleny Danielewiczowej:}

$\mathrm{w}$ badaniach semantycznych istotne jest najmniejsze nawet zróżnicowanie formalne. Dotyczy to nie tylko różnic segmentalnych, lecz także opozycji związanych $z$ wystrojem prozodycznym języka czy z linearnym uporządkowaniem badanych wyrażeń. Należy się spodziewać (a w każdym razie nie można tego $z$ góry odrzucić), że za takim zróżnicowaniem płaszczyzny stoi zróżnicowanie dotyczące płaszczyzny treści [Danielewiczowa 2012, 33].

W wypadku opisywanych leksemów mamy do czynienia właśnie $z$ różnicą segmentalna, dziwi więc swoboda leksykografów w zrównywaniu znaczenia wyczynu z pewnym rodzajem czynu. W swoim artykule przyjrzę się zatem leksemom wyczyn oraz czyn i podam argumenty świadczace o tym, że znaczenie słowa wyczyn nie może być sprowadzone do treści zawartych w wyrażeniu wyjatkowy czyn. W obrębie moich zainteresowań znajdują się jednostki nazywające działania. A jak twierdzi Anna Wierzbicka [2010, 69],

Pojęcia 'działania' i 'zdarzenia', tj. 'robienia' i 'dziania się', odgrywają w dyskursie międzyludzkim niezwykle ważna rolę. O tym sa w gruncie rzeczy wszystkie historie i opowiadania - co się stało i co zrobiła ta czy tamta osoba.

Pojęcie ROBIĆ uznawane jest przez Andrzeja Bogusławskiego [1991] i Annę Wierzbicką [2010] za nieredukowalną elementarna jednostkę języka, która ze względu na swą prostotę i uniwersalny charakter powinna stać się podstawą definicji innych, bliskich jej znaczeniowo wyrażeń, wśród których niewątpliwie znajduje się leksem wyczyn.

W ISJP wyrażeniu wyczyn oprócz przywołanego wyżej znaczenia przypisano jeszcze dwa inne:

2.'Czyjeś wyczyny to postępki tej osoby, naruszające jakieś normy prawne lub obyczajowe. Słowo używane $z$ dezaprobatá'.

3. 'Wyczyn to uprawianie sportu w celu osiagnięcia rekordowych wyników. Słowo używane przez sportowców i dziennikarzy sportowych' (przykład ze słownika: Znalezienie odpowiedniego sprzętu do wyczynu nie jest proste).

Warto zwrócić uwagę, że w SJPDor wyodrębniono tylko dwa znaczenia słowa wyczyn, żadne nie jest objaśniane $z$ użyciem hiperonimu czyn, a definicje brzmią następująco:

1. 'Niecodzienne, wybitne osiagnięcie, zwłaszcza w dziedzinie sportu';

2. 'Wybryk, swawola. Słowo potoczne $z$ odcieniem ujemnym'.

W ISJP dodano zatem trzecie znaczenie analizowanego słowa, które jest wynikiem uniwerbizacji innej jednostki leksykalnej, a mianowicie wyrażenia sport wyczynowy. 
Intuicja podpowiada, że słowo wyczyn w potocznym rozumieniu przede wszystkim kojarzy się ze sportem i osiaganiem w nim sukcesów, co dobrze oddaje następujaccy opis:

Andrzej Bargiel dokonał wyczynu, który dotą $w$ głowie się nie mieścił. Pionierski zjazd na nartach z K2 (8611 m), najtrudniejszego i najbardziej niedostępnego ośmiotysięcznika zapisuje złotymi zgłoskami nazwisko Bargiela $w$ historii polskiego $i$ światowego himalaizmu. ${ }^{2}$

Odwołanie do „osiagnięć w dziedzinie sportu” zawarte jest wprost w przytoczonej wyżej definicji SJPDor. W ISJP brak wzmianki o tym, że „wyjątkowy czyn” może mieć związek ze sportem, a wśród przykładów pod pierwszym ze znaczeń słowa wyczyn mamy: Dokonał śmiałego wyczynu, przepływajac samotnie Atlantyk...; ...nieprawdopodobny wyczyn polskiego pilota. W ISJP zwrócono uwagę, że wyczyny jako postępki (znaczenie drugie) przybieraja postać liczby mnogiej, przykład: Komendant posterunku wiedział o wszystkich wyczynach Kaźmierczaka. Kolejne analizowane przeze mnie wypowiedzi z użyciem omawianego wyrazu potwierdzą tezę: w drugim słownikowym znaczeniu objaśniany rzeczownik [SJPDor i ISJP] występuje jako plurale tantum.

W opisie semantyki słowa nie sposób odciąc się od innych jego znaczeń i będę je brała pod uwagę. Chciałabym jednak zaznaczyć, że w tym artykule za cel stawiam sobie znalezienie różnic semantycznych między pierwszym znaczeniem słowa wyczyn a słowem czyn, scharakteryzowanym w ISJP jako „raczej książkowe” i definiowanym następująco:

1.'Coś, co ktoś zrobił lub ma zrobić, zwykle coś ważnego i dobrego'.

2. 'Coś złego, co ktoś zrobił'.

W ISJP, inaczej niż w słowniku pod red. W. Doroszewskiego, w którym leksem czyn objaśniony został za pomoca glosy: 'postępek, uczynek; dzieło', wyodrębniono dwie bliskie semantycznie jednostki leksykalne, rozróżnione ze względu na przypisywana im wartość. Jeśli czyn jest dobry, mamy do czynienia $z$ pierwszą $z$ nich, jeśli zły $-z$ drugą. Wartościowanie w kategoriach 'dobry' i 'zły' stanowi podstawe etyki, ale jest również - jak twierdzi A. Wierzbicka - stale obecne w potocznym myśleniu:

w refleksji na temat życia pojęcie 'złych (dobrych) rzeczy, które przytrafiaja się ludziom' zajmuje centralne miejsce (...), a idea 'kogoś robiącego coś złego' (lub w mniejszym stopniu 'coś dobrego') leży u podstaw etyki i prawa [Wierzbicka 2010, 69].

Analiza przykładów z NKJP pozwala stwierdzić, że słowo czyn zawsze pojawia się w kontekstach, $z$ których daje się wyczytać jego pozytywną bądź negatywną ocenę. Najczęściej te określenia będą wyrażane explicite

2 Przykłady użyte w artykule w większości pochodzą z NKJP: http://nkjp. $\mathrm{pl} /$, a jeśli jest inaczej, zaznaczam to. 
przez przydawki typu: wielki, bohaterski, heroiczny, szlachetny, śmiały, odważny, chwalebny czy z drugiej strony - karygodny, zły, straszliwy, haniebny, zbrodniczy, nieopatrzny, najstraszniejszy, odrażajacy, nierozważny, niecny, wykrętny, bestialski. Oto przykłady:

(1) Najprostsza droga do osiagnięcia celu wydało mu się dokonanie jakiegoś niezwykłego czynu.

(2) Jeślibym miał siedzieć bezczynnie, pracować dla siebie, dla jakiejś ambicyjki, rodziny, familii, wsi, powiatu, uczyć się dla samej nauki, nie dla spetnienia wielkiego czynu, czynu-skoku ludzkości, to zabij mie jak nędznego psa!

(3) Widzisz, inni maja swoje drzewa genealogiczne, ich historie tworza bohaterskie czyny, których dokonali ich pradziadowie i dziadowie.

(4) Pokochałem ja tak bardzo, że gdyby zażadała ode mnie dokonania najstraszniejszego czynu, zrobitbym to bez wahania.

(5) Najbardziej go dziwiło to, że w czasie całej rozmowy z Rysiem, tam, $w$ cieniu kościoła, popełnienie zbrodniczego czynu wydawało mu się czymś zwyczajnym i obojętnym.

(6) Nasuwa się refleksja: jeżeli nieletni dopuszcza się tak okrutnego czynu, czy nie należałoby karać go jak człowieka dorosłego, w pełni odpowiedzialnego za swoje czyny?

Z powyższych zdań jasno wynika, o jakim czynie mowa - dobrym czy złym. W miejscu przydawki zamiast przymiotników określających leksem czyn można wstawić przymiotnik dobry albo zły, np.:

(1a) Najprostsza droga do osiagnięcia celu wydało mu się dokonanie jakiegoś do brego czynu.

(5a) Najbardziej go dziwiło to, że w czasie całej rozmowy z Rysiem, tam, w cieniu kościoła, popetnienie złe go czynu wydawało mu sie czymś zwyczajnym i obojętnym.

Jeśli informacja o tym, czy mamy do czynienia ze złym czy dobrym czynem nie jest podana wprost za pomoca odpowiedniej przydawki, można to wyczytać $z$ kontekstu wypowiedzi.

(7) Sad przyją, że Rokossowski dokonał czynu „pod wpływem silnego wzruszenia duchowego" $i$ skazał go tylko na 4 lata ciężkiego więzienia.

(8) Długo będa jeszcze opowiadać o owym czynie i sławić twoje męstwo na wieki.

Można zatem uznać za zasadniczo trafne rozpoznanie leksykografów, którzy w strukturze semantycznej leksemu czyn wyodrębniają elementy odwołujące się do działania ('coś, co ktoś zrobił') i elementy wartościujacee. Według Karola Wojtyły: „Tylko działanie, które zakłada jako działacza osobę - stwierdziliśmy, że tylko takie zasługuje na nazwę "czyn" - odznacza się moralnością" [Wojtyła 2000, 60]. Wartości moralne stano- 
wią według Wojtyły „nie tylko wewnętrzną właściwość ludzkich czynów, ale mają też to do siebie, że człowiek właśnie jako osoba poprzez te moralnie dobre lub złe czyny sam staje się dobry lub zły" [tamże, 61]. Autor wspomina wprawdzie o „czystym” czynie, jednak dodaje, że abstrahowanie czynu ludzkiego od wartości moralnych byłoby sztuczne.

Analiza przykładów pochodzacych $z$ NKJP oraz Internetu pozwala stwierdzić, że leksem wyczyn określają następujące przydawki jakościowe: wielki, ekstremalny, śmiały, nadludzki, nieprawdopodobny, niesamowity, niebywały, niezwykły, nie byle jaki, nie lada wyczyn, wyjatkowy, rzadko spotykany, sensacyjny, duży itd. Przymiotniki te najczęściej wyrażaja skrajna ocenę opisywanej rzeczywistości i informuja nas o czymś, czym jesteśmy pozytywnie zaskoczeni, co podziwiamy. Trudniej przywołać wypowiedzi $z$ użyciem negatywnie nacechowanych przydawek określajacych rzeczownik wyczyn. Zdania (14) i (15) to fragmenty internetowych notatek prasowych, których warstwa językowa budzi pewne zastrzeżenia. Przede wszystkim uderza wzajemne wykluczanie się postawionych obok siebie wyrazów: przymiotniki bestialski czy okrutny semantycznie „nie pasuja” do rzeczownika wyczyn. Sa to przykłady niefortunnych realizacji jednostki, której prymarna postacia jest plurale tantum. Nie sposób w miejsce przydawki w zdaniach (9)-(15) wstawić przymiotnik dobry lub zły.

(9) W końcu mogę wyjawić Ci sposób, dzięki któremu dokonam swego wszechświatowego wyczynu i powróce w nasz wymiar // *dokonam swego dobrego wyczynu...

(10) Dokonaliśmy niezwykłego wyczynu. Nasza brygada zlikwidowała groźna bandę złodziei // *Dokonaliśmy dobrego wyczynu...

(11) Gdy wróciłam $z$ podróży po Europie, oczywiście zastałam $w$ mieszkaniu stosy nowych listów. Moja dzielna gosposia Maria dokonała prawdziwie heroicznego wyczynu, segregujac je - w jednym miejscu ułożyła depesze oficjalne, $w$ innych listy od widzów z Niemiec, Włoch, Francji.. // *Moja dzielna gosposia Maria dokonała dobrego wyczynu...

(12) - Do zobaczenia - rzekł Ćwikła, po czym wciagnał oddech tak głęboko, jakby zamierzał dokonać niestychanego wyczynu: wcisnać między żebra swój, przypominajacy nadmuchana piłkę plażowa, brzuch // *dobrego wyczynu.

(13) Głównodowodzacy powinszował kapitanowi z powodu śmiałego czynu, a Admiralicja pragnie dodać swe gratulacje wobec pięknego wyczynu // *wobec dobrego wyczynu.

(14) "Prokuratura nie wyklucza, że czwórka nastoletnich bandytów, którzy w Gliwicach (woj. śląskie) skatowali 16-letniego Daniela E., odpowie za swój okrutny wyczyn // *odpowie za swój zły wyczyn.

(15) "Bestialski wyczyn starszej pani. Zawinęła szczeniaki $w$ foliowy worek $i$ wyrzuciła do śmieci // *Zły wyczyn starszej pani. 
Zdarzają się też zdania bez przydawek określających omawiany rzeczownik, np.:

(16) Dokonat on wtedy wyczynu.

(17) Byłem na fali i pewnie dlatego dokonałem wyczynu, który chwile wcześniej przekraczałby moje możliwości.

(18) Jako jedyny z dziesięcioosobowej ekipy dokonat tego wyczynu, pokonujac kajakiem i pontonem każdy kilometr rzeki.

W ISJP, o czym wspominałam, zwrócono uwagę, że wyczyny jako 'postępki naruszające normy' (znaczenie drugie) to jednostka semantycznie nacechowana negatywnie, dla której prymarna jest forma liczby mnogiej. Oto przykłady:

(19) Otóż ten osobnik w filmie - ciagnął Marks - zabijał, powtarzając wyczyny innych morderców.

(20) Główni bohaterowie nie grzesza inteligencja, więc czytelnik obserwuje ich glupawe wyczyny, czyta durnowate (choć czasem zabawne) dialogi, a fabuła po sznureczku idzie od jednego punktu do następnego.

(21) Nie będe opisywać „świętego szaleństwa” talibów, wyczynów irańskiej rewolucji czy algierskiej masakry.

(22) W dodatku haniebne wyczyny skrajnie prawicowych formacji podziemia, które mordowało zwiazanych z AK pracowników Biura Informacji Prasowej (BIP-u)...

Z dokonywaniem złych czynów czy wyczynów, a także $z$ niedokonywaniem czynów dobrych, wiąże się niewątpliwie pojęcie odpowiedzialności. Krzysztof Gajewski twierdzi, że: „być moralnie odpowiedzialnym za jakieś działanie oznacza tyle, co zasługiwać na pochwałę lub potępienie za wykonanie tego działania" [Gajewski 2009, 4]. Pochwała zaś i potępienie zgodnie $z$ wykładnią Arystotelesa wiażą się $z$ możliwością dokonania świadomego wyboru: „pochwała i nagana odnosza się do tego, co zależne od woli (...). Otóż za niezależne od woli uchodzą te rzeczy, których dokonywa się bądź pod przymusem, bądź skutkiem nieświadomości" [Arystoteles 2000, 122]. Odpowiedzialności nie ponosi zatem nieświadome skutków swych działań dziecko czy zwierzę. $Z$ drugiej strony odpowiedzialność może ponieść ktoś, kto nie popełnił złego czynu, ale jest odpowiedzialny za kogoś, np. za dziecko czy zwierzę, które zrobi coś złego. Kwestie te były przedmiotem refleksji semantycznej Izabeli Duraj-Nowosielskiej:

kiedy mówię, że ktoś coś zrobił, obarczam podmiot odpowiedzialnościa za jakieś obiektywne zdarzenie skutkowe, ale wraz z przypisaniem mu odpowiedzialności otwieram się na perspektywę samego podmiotu, na to, co on sam ma mi do powiedzenia. 
Stąd wniosek, że odpowiedzialne - zdolne do odpowiadania-moga być jedynie istoty mówiące. To oczywiście kłóci się $z$ faktem, że podmiotami predykatów agentywnych moga być również zwierzęta. W ich wypadku zrobienie czegoś rzeczywiście nie implikuje odpowiedzialności (...), ale też - zauważmy - w odniesieniu do zwierząt nie mówi się ani o działaniach, ani o czynnościach [Duraj-Nowosielska 2007, 99].

\section{I dalej:}

przypisując osobie $x$ jakiś predykat agentywny, obarczamy ją odpowiedzialnością za dane zdarzenie, co jest możliwe jedynie przy założeniu, że osoba ta mogła wpłynąc na to, żeby zdarzenie $z$ nie zaszło. U podstaw takiego myślenia leży $z$ kolei przekonanie, że osoba $x$ jest $z$ zasady wolna i może swoją wolą wpływać na bieg wydarzeń (...). Praktyka stosowania konstrukcji agentywnych pokazuje, że ów warunek „wolnościowy” nie jest ograniczony do czasu zdarzenia $z$ - może być tak, że w chwili $t_{z}$ osoba $x$ „nic już nie mogła zrobić" - jednak wcześniej mogła postapić tak, że do zdarzenia $z$ potem by nie doszło [2007, 120].

Przykłady (23)-(26) są potwierdzeniem ludzkiej odpowiedzialności za czyny:

(23) - Chłopak ma 19 lat, jest pelnoletni i odpowiedzialny za swoje czyny. Nie chciałabym, aby z jego powodu szargane było dobre imie klubu sportowego, który odnosi wielkie sukcesy.

(24) Jeśli kol. Bak jest odpowiedzialny za swoje czyny-naszym obowiazkiem jest wykluczenie go ze Zwiazku.

(25) Sąd najpierw stwierdzit, że Skog był w pełni zdrowy i odpowiedzialny za swoje czyny. Tym samym winny morderstwa.

(26) Zawodnik jest odpowiedzialny za swoje czyny i ponosi za nie konsekwencje.

Gdy dopełnieniem w podobnych konstrukcjach będzie rzeczownik wyczyn // wyczyny, zdania staja sie jednoznaczne: będzie w nich mowa o wyczynach jako 'postępkach naruszających normę' (drugie znaczenie $z$ ISJP).

(27) *Osoba odpowiedzialna za hakerski wyczyn wydaje sie być 19-latek [przykład z Internetu].

(28) Brednie Kowalczyka o braku odpowiedzialności za wyczyny ich pracownika sa godne wyłacznie idioty [przykład z Internetu]. (29) *Małysz jest odpowiedzialny za swój wyczyn w Oslo [przykład własny].

Wypowiedzi o odpowiedzialności za wyczyny w znaczeniu 'postępki' na próżno szukać w NKJP. Podobnie było $z$ kontekstami użyć połączeń typu: pies dokonat wyczynu (42) i (43) czy okrutny, bestialski wyczyn (14) i (15), które zostały znalezione w Internecie. Powodem tego braku najpewniej jest to, że przytoczone przykłady nie sa zgodne $z$ norma pol- 
szczyzny. Korpus, jak wiadomo, w znacznej części jest zbiorem tekstów zredagowanych (prasa, literatura piękna), a artykuły internetowe nierzadko cechuje niski styl wypowiedzi ( $z$ licznymi błędami na każdym poziomie - od literówek po semantykę). W zdaniu (27) powinien zostać użyty rzeczownik wyczyny, który, jak wspominałam, w tym znaczeniu ma postać plurale tantum.

I. Duraj-Nowosielska pisze:

ważne (...), aby sobie uświadomić, że w analizie semantycznej zdań języka naturalnego nie można tak po prostu, bez żadnych dalszych konsekwencji, zrezygnować $z$ pojęć takich jak intencjonalne działanie, podmiot działający itd., ściślej mówiąc - nie można zrezygnować $z$ językowych korelatów tych pojęć, przede wszystkim predykatu [ktoś] coś zrobił / robi ([ktoś] coś zrobił / robi z [czymśn) [Duraj-Nowosielska 2007, 73].

Badaczka przypomina też ustalenia A. Bogusławskiego, który twierdzi, że „argument ktoś występuje pierwotnie jako podmiot wiedzy ([ktoś.] wie o [czymśs] [coś] i jako podmiot działania ([ktoś] coś robi / zrobił (z [czymś])); wszystkie predykaty epistemiczne i agentywne maja zatem podmioty osobowe" [cyt. za: I. Duraj-Nowosielska 2007, 21; charakterystyka wyrażeń ktoś i coś oparta na materiałach $z$ seminarium A. Bogusławskiego]. Ścisły związek pojęć ‘czyn' i 'osoba' podkreśla również Czesław Stanisław Bartnik, według którego czyn jest intelektualno-wolitywnym działaniem człowieka jako osoby, działaniem świadomym i twórczym:

Tylko osoba czyni, czyli działa, postępuje, dokonuje aktów moralnych, tworzy historię (...) Osoba spełnia się przez czyn w swej istocie i w swym istnieniu [Bartnik 2000, 281].

W tej krótkiej wypowiedzi autor zwraca uwagę na istotę czynu - może go dokonać tylko człowiek, i tylko człowiek jako osoba. Podobnie Karol Wojtyła uważa, że osoba spełnia się przez swój czyn, przez czyn urzeczywistnia siebie jako „ktoś” i jako „ktoś” też siebie ujawnia:

Chociaż bowiem operari sequitar esse - zatem osoba i jej wartość jest wcześniejsza od wartości czynu i w stosunku do niej podstawowa - to przecież równocześnie osoba ujawnia się poprzez czyny (...) [Wojtyła 2000, 305; zob. również Wojtyła 2000, 201].

Odnosząc te treści do przykładów zdań ze słowem czyn, można stwierdzić, że czynu dokonuje tylko człowiek [por. (30)-(33), przykłady własne].

(30) Piotr dokonał wielkiego czynu.

(31) *Pies dokonat wielkiego czynu.

(32) *Kot dokonał wielkiego czynu.

(33) *Mucha dokonała wielkiego czynu.

Wyczyny zaś, w przeciwieństwie do czynów, moga być przypisane zwierzętom, o czym świadczą zdania (34)-(43) [zaczerpnęłam je z In- 
ternetu]. Wśród przykładów z użyciem słowa wyczyn przeważają te, w których o relacjonowanym zdarzeniu $z$ udziałem zwierzęcia mówimy: wyczyn!, ale wyczyn!, jakiś wyczyn (bohaterski, rekordowy), wyczyn czyjś (psa, rybołowa, słonia), a znacznie mniej jest zdań o zwierzętach, gdy ich nazwy występują w pozycji mianownika, otwieranej dla agensa, np. ?Pies dokonał bohaterskiego wyczynu.

(34) Bohaterski wyczyn psa zarejestrowała kamera przemysłowa (rottweiler uratowat chihuahua przed kojotem).

(35) Ekstremalne wyczyny psa na deskorolce.

(36) Czteroletnia psinka szczeka z natężeniem 108 decybeli. Wyczyn trafi do Ksiegi rekordów Guinnessa.

(37) Ostatni, wielki wyczyn Lampo - uratowanie życia małej Adele - przypieczętował jego wielka miłość do ludzi.

(38) Bohaterski wyczyn bezpańskiego psa. Zabłakany pitbull znalazł nowy dom po tym, jak $w$ bohaterski sposób uratował życie pewnej kobiecie. Zwierze zasłoniło ja własnym ciałem przed atakiem nożownika. (39) Rekordowy wyczyn rybołowa. Przeleciał prawie 7 tys. $\mathrm{km} z$ Finlandii do Kenii.

(40) Niesamowity wyczyn słoni. Uratowały tonace młode.

(41) W niedziele biegacz i jego przyjaciele dokonali historycznego wyczynu. Panek jako pierwsza niewidoma osoba przebiegt nowojorski pótmaraton $z$ pomoca psów przewodników.

(42) ? Jak donosi francuska telewizja France 3 Occitanie, dzielny czworonóg dokonat wielkiego wyczynu.

(43) ?Pies mojego taty dokonat takiego wyczynu.

Zdania (42) i (43) budzą wattpliwości poprawnościowe. Czy zwierzę może czegoś dokonać? Warto w tym kontekście przywołać formułę, za pomoca której A. Bogusławski opisuje znaczenie czasownika dokonać, prawostronnie otwierajacego miejsce na rzeczowniki czyn i wyczyn:

(...) agens działa rozmyślnie tak, by pewien przedmiot już istniejący wraz z jego odpowiednia cecha (oznaczana przez właściwy rzeczownik) przeszedł w nowy stan (ten stan jest oznaczany przez właściwe abstractum), przy czym ta zmiana jest w swoim układzie odniesienia doniosła (nie jest zwykła i pozbawiona szczególnych konsekwencji); rozumie się tu, że zmiana nie polega na pojawieniu się samego działania in abstracto; to właśnie wyklucza nie tylko wyrażenia typu dokonał rozdarcia spodni, lecz również typu dokonał krzyknięcia lub dokonat ruchu ręka (...) [Bogusławski 1978, 22].

Agensowi przypisane jest w niej działanie rozmyślne. A czy rozmyślnie może działać zwierzę? ${ }^{3}$

${ }^{3}$ I. Duraj-Nowosielska pisze o szczególnych sytuacjach, kiedy o zwierzęciu myślimy jako o „kimś”. Dotyczy to udomowienia i nadania imienia. Zgodnie $z$ ta teoria zaakceptować można zdanie: Czteroletni pies pasterski o imieniu Pero do- 


\section{PODSUMOWANIE}

Celem mojego opisu było wykazanie różnic znaczeniowych między leksemami wyczyn i czyn i zwrócenie uwagi na to, że głównym składnikiem definiensa w definicji słowa wyczyn nie powinno być wyrażenie 'wyjatkowy czyn'. Choć oba omawiane rzeczowniki moga być dopełnieniem czasownika dokonać, a w polszczyźnie znajdziemy przykłady użyć, na podstawie których da się stwierdzić, że badane jednostki semantycznie w pewnych kontekstach sa sobie bardzo bliskie, to jednak różniące je cechy sa nietrudne do uchwycenia. Rzeczowniki te najczęściej określa się innymi przydawkami (rzeczownik czyn dopełni przydawka bohaterski, szlachetny, wielki, okrutny, bestialski itp., pozytywnie skrajne określenia leksemu wyczyn wyrażające podziw i zaskoczenie mówiącego to m.in.: nieprawdopodobny czy ekstremalny. Czyn jako zachowanie wyłącznie ludzkie jest uwikłany w moralność, zawsze kwalifikowany jako dobry albo zły. Podmiotem wypowiedzi z użyciem leksemu czyn nie może być zwierzę, ponieważ ono nie działa rozmyślnie (za dewiacyjne uznamy konstrukcje: *Pies dopuścił się karygodnego czynu // *Koń dokonał wielkich czynów). Za czyny jesteśmy odpowiedzialni i ponosimy ich konsekwencje. Za wyczyny odpowiadamy tylko wtedy, gdy można je określić za pomoca jednostki definiowanej jako 'postępki naruszające normy', czyli wyczyny [ISJP].

Hannah Arendt $[1996,100]$ wymienia trzy sensy, w których można mówić o działaniu człowieka - trzy przejawy vita activa: 1) labour - to „trud ciała”, skierowany na podtrzymanie procesów życiowych; 2) work, fabrication - praca „wytwórcza”; 3) action-działanie we właściwym sensie tego słowa, zachodzące pomiędzy ludźmi, dzięki któremu wyróżniają się oni wśród równych sobie. Sens zawarty w słowach czyn i wyczyn to niewatpliwie sens action, jednak dodatkowo podzielony na działanie dla kogoś (dobry czyn) bądź przeciw komuś (zły czyn) i takie działanie, które choć odbywa się w obecności innych i często jego celem jest sprawienie innym radości, to jednak jest aktywnościa, której cel zasadniczy stanowi zrobienie czegoś dla siebie (wyczyn). Różnicy między czynem a wyczynem dotyczą ostatnie sformułowania w definicji wyróżnionego przez H. Arendt sensu action, chodzi mianowicie o sposób wyróżniania się ludzi wśród równych sobie podczas podejmowanych przez siebie działań. Gdy mówimy o dobrym czynie, zwracamy uwage przede wszystkim na poświęcenie względem kogoś innego. Człowiek dokonujący dobrego czynu często ryzykuje własne życie lub zdrowie. O dobrym czynie powiemy: 'ktoś zrobił coś dobrego dla kogoś'. Wy c zy n e m zaś nazwiemy rekordowo długi skok narciarza, który ciężko i długo pracował,

konał nie lada wyczynu. Przemierzył samodzielnie $w$ ciagu 12 dni niemal 400-kilometrowa trasę $z$ Cockermouth położonego na północy Anglii do Penrhyncoch $w$ Walii, ponieważ pies Pero to niewątpliwie „ktoś” [2007, 24; 2001]. 
by przed publicznościa pokazać swe umiejętności, jednak jego dokonania sa $z$ etycznego punktu widzenia nieporównywalnie mniej wartościowe $\mathrm{w}$ zestawieniu $\mathrm{z}$ ocaleniem komuś życia (które nazwiemy dobrym czynem) i niewątpliwie głównie służą samemu skoczkowi (w jakimś stopniu też kibicom czy fanom). Powołując się na wybrane fragmenty definicji $z$ ISJP i WSJP, wyczyn można scharakteryzować następujacco: 'ktoś zrobił coś wyjątkowego, co zdarza się rzadko i jest bardzo trudne, ponieważ wymaga wielu umiejętności lub wielkiego wysiłku i $z$ tego powodu budzi podziw innych osób'. Przytoczona definicja, w przeciwieństwie do propozycji wskazanych słowników, nie nazywa wyczynu czynem. Uzasadnienie takiego wyboru zawarłam w powyższych rozważaniach.

\section{Bibliografia}

H. Arendt, 1996, Wola, Warszawa.

Arystoteles, 2000, Etyka nikomachejska, Warszawa.

ISJP: M. Bańko (red.), 2001, Inny słownik języka polskiego, t. I-II, Warszawa.

C.S. Bartnik, 2000, Personalizm, Lublin.

A. Bogusławski, 1978, Jednostki języka a produkty językowe. Problem tzw. orzeczeń peryfrastycznych [w:] M. Szymczak (red.), Z zagadnień współczesnego języka polskiego, Wrocław, s. 17-30.

A. Bogusławski, 1991, Semantic primes for agentive relations, „Lingua Posnaniensis" XXXII/XXXIII, Poznań, s. 39-64.

A. Bogusławski, 2008, Semantyka, pragmatyka. Leksykografa głos demarkacyjny, Warszawa.

M. Danielewiczowa, 2006, Do czego służy słowo raczej?, „Polonica” XXVI-XXVII, s. 83-100.

M. Danielewiczowa, 2012, W głąb specjalizacji znaczeń. Przysłówkowe metapredykaty atestacyjne, Warszawa.

I. Duraj-Nowosielska, 2001, O 'działaniach' $i$ 'wypadkach'- równobrzmiace, wielowalentne czasowniki z podmiotami osobowymi (ktoś) i nieosobowymi (coś), „Biuletyn PTJ” LVII, Kraków, s. 21-54.

I. Duraj-Nowosielska, 2007, Robić coś $i$ coś powodować. Opozycje agentywności i kauzatywności w języku polskim, Warszawa.

K. Gajewski, 2009, Odpowiedzialność moralna i posłuszeństwo, online: https:// www.krzysztofgajewski.info/pdf/popularyzacja/2009_Odpowiedzialnosc.pdf [dostęp: 5.06.2020 r.].

R. Ingarden, 1975, Ksiażeczka o człowieku, Kraków.

SJPDor: W. Doroszewski (red.), 1958-69, Słownik języka polskiego, t. I-XI, Warszawa.

A. Wierzbicka, 2010, Semantyka. Jednostki elementarne i uniwersalne, Lublin.

K. Wojtyła, 2000, Osoba i czyn $i$ inne studia antropologiczne, Lublin.

WSJP: P. Żmigrodzki (red.), 2007-2018, Wielki słownik języka polskiego PAN, www.wsjp.pl [dostęp: 21.07.2020 r.]. 
Preliminary remarks on the semantics of the lexemes wyczyn (a feat) and czyn (an act)

\section{Summary}

In this paper, the author analyses the Polish nouns czyn (an act) and wyczyn (a feat). She aims to find semantic differences between these units. The author quotes selected dictionary definitions, analyses examples from NKJP (National Corpus of Polish); in her discussions, she refers to both philosophical theories (by H. Arendt, Cz.S. Bartnik, R. Ingarden, K. Wojtyła), and linguistic diagnoses (by A. Bogusławski, M. Danielewiczowa, I. Duraj-Nowosielska, A. Wierzbicka). The author concludes that, despite the guidance provided in some lexicographic studies, the lexeme wyczyn cannot be defined with the phrase 'wyjatkowy czyn' (an exceptional act).

Keywords: semantics - lexis - lexicography

Trans. Monika Czarnecka 